\title{
Vitamin D-Regulated, ATP-Dependent Calcium Transport by Intestinal Golgi Vesicles during Maturation in the Rat
}

\author{
NOUSHIN ARAB AND FAYEZ GHISHAN \\ Division of Gastroenterology Nutrition, Department of Pediatrics, Vanderbilt Medical School, \\ Nashville, Tennessee 37232
}

\begin{abstract}
The developmental aspects of Calcium uptake by intestinal Golgi vesicles was determined using highly purified Golgi vesicles from enterocytes of suckling ( 2 wk old), weanling ( 3 wk old), and adolescent ( 6 wk old) rats. Calcium uptake by Golgi vesicles at all age groups represented transport into the intravesicular space as evident by temperature dependency and by calcium ionophore A23187-induced calcium efflux studies. Calcium uptake was driven by ATP at all age groups, however, maximal uptake at 15 min was significantly greater in Golgi vesicles of adolescent rats compared to mean values in Golgi vesicles of suckling rats $(p<0.01)$. Calcium uptake in the absence of ATP was minimal. The requirement for the adenine base and the hydrolysis of the $\beta$ - $\gamma$-phosphodiester was tested by replacement of ATP in the incubation media by CTP and the nonhydrolyzable ATP analogue, adenylyl( $\beta$ - $\gamma$-methylendiphosphonate). Both agents had no stimulatory effect on calcium uptake. Calcium uptake was linear up to $40 \mathrm{~s}$. Kinetic parameters of calcium uptake at free calcium concentrations of 0.04 to $1.0 \mu \mathrm{M}$ showed a maximal transport capacity of $0.99 \pm 0.05,0.55 \pm 0.04$, and $0.29 \pm 0.03 \mathrm{nmol} / \mathrm{mg}$ protein $/ 15 \mathrm{~s}$ for adolescent, weanling, and suckling rats, respectively. $\mathrm{Km}$ values were $0.16 \pm$ $0.02,0.12 \pm 0.03$, and $0.07 \pm 0.02 \mu \mathrm{M}$ for adolescent, weanling and suckling rats, respectively. $\mathrm{Km}$ and $\mathrm{V}_{\max }$ values were significantly different between adolescent and suckling rats $(p<0.01)$. The calcium regulatory protein calmodulin has no effect on calcium uptake by Golgi vesicles. Vitamin D deficiency in all age groups decreased ATP-dependent calcium uptake. Administration of 1,25$(\mathrm{OH})_{2}$ vitamin $D_{3} 8 \mathrm{~h}$ before death enhanced ATP-dependent calcium uptake in all age groups studied. This enhancement was the result of increase in maximal transport capacity of ATP-dependent calcium uptake. This study demonstrates a vitamin D-regulated ATP-driven calcium uptake by intestinal Golgi vesicles at all age groups including the suckling period. This transport system shows developmental patterns in regard to its kinetic parameters. (Pediatr Res 26: 58-62, 1989)
\end{abstract}

\section{Abbreviations}

$1,25(\mathrm{OH})_{2} \mathrm{D}_{3}, 1,25(\mathrm{OH})_{2}$ vitamin $\mathrm{D}_{3}$ AMP-PCP, adenylyl- $(\beta-\gamma$-methylendiphosphonate $)$

Received December 12, 1988; accepted March 16, 1989

Correspondence to Fayez K. Ghishan, M.D. Professor of Pediatrics, Director, Division of Pediatric Gastroenterology and Nutrition, Vanderbilt Medical School, Nashville, TN 37232

Supported by HHS DK33209-05.
Calcium movement across the cytosol of the enterocyte remains controversial. The concept of calcium sequestration during transcellular transport has been suggested. Two modes of calcium sequestration have been postulated: 1) Equilibrium binding to high affinity sites on cytosolic membranes or soluble protein (1-3); and 2) Active calcium sequestration against electrochemical gradient in subcellular organelles (4-8). Warner and Coleman (9) using electron probes have shown an electron-dense intracellular calcium deposits in the area of Golgi membranes and lysosomes of the small intestine of vitamin D-depleted rats. The Weiser group has shown in adult rat small intestine that Golgi vesicles bind calcium avidly in a biphasic manner (10). This binding is decreased with vitamin D deficiency and is increased with vitamin D treatment (10). The initial method of preparing Golgi vesicles involved scraping of intestinal mucosa thus resulting in high nonesterified fatty acid which binds calcium (7). Recently Golgi vesicles were prepared from freshly isolated enterocytes. This method allowed detection of an ATPdependent calcium transport system (8). Because calcium binding proteins are absent during the suckling period (11), we hypothesized that the intracellular organelles may play a role in intracellular calcium movement. The present studies were designed to investigate the role of Golgi in calcium transport during maturation. Moreover, we investigated the role of vitamin $D$ in this process. Using a modified technique originally described to prepare liver Golgi membranes, we isolated highly purified Golgi vesicles from intestinal enterocytes and characterized calcium transport by Golgi vesicles and its regulation by vitamin $D$ in the rat during maturation.

\section{MATERIALS AND METHODS}

Animals and diet. Male Sprague-Dawley adolescent $(42 \pm 2$ days), weanling ( $21 \pm 1$ day), and suckling (14 \pm 1 day) rats (Harlan, Indianapolis, IN) were used for all experiments. Suckling rats were allowed to suckle from their mother. Weanling and adolescent rats were fed regular food containing $1.2 \% \mathrm{cal}-$ cium, $0.8 \%$ phosphate, and $1700 \mathrm{U} / 100 \mathrm{~g}$ of ergocalciferol (Teklad Diets, Madison, WI). Vitamin D-deficient rats were fed vitamin $\mathrm{D}$-deficient diet $(0.4 \% \mathrm{Ca}, 0.3 \% \mathrm{P})$ obtained from Teklad Diets (Madison, WI) and kept in the dark. Vitamin D deficiency in suckling rats was induced by feeding pregnant dams a vitamin D-deficient diet $48 \mathrm{~h}$ beginning after insemination. Upon delivery, the pups suckled mothers milk while continued on vitamin D-deficient diet. Both mothers and suckling rats were kept in the dark. Vitamin D deficiency in adolescent rats was induced by feeding weanling rats the vitamin $\mathrm{D}$-deficient diet for $4 \mathrm{wk}$ while being kept in the dark. Rats were killed by cervical dislocations and the enterocytes were prepared from jejunal segments by the method of Weiser (12). The jejunal region extended from the ligament of Treitz to 20,30 , and $50 \mathrm{~cm}$ aborally in suckling, 
weanling, and adolescent rats, respectively. The intestinal segments were removed, flushed with ice-cold normal saline and then filled with warmed buffer solutions $\left(37^{\circ} \mathrm{C}\right)$ containing 1.5 $\mathrm{mM} \mathrm{KCl}, 96 \mathrm{mM} \mathrm{NaCl}, 8 \mathrm{mM} \mathrm{KH}_{2} \mathrm{O}_{4}, 5.6 \mathrm{mM} \mathrm{Na}_{2} \mathrm{HPO}_{4}, 27$ $\mathrm{mM} \mathrm{Na}$ citrate, and $2 \mathrm{mM}$ dithiothreitol, $\mathrm{pH}$ 7.2. The segments were clamped and incubated in the same buffer without dithiothreitol (this buffer will be called citrate buffer from here after) for $15 \mathrm{~min}$ in a shaking water bath at $37^{\circ} \mathrm{C}$. The clamps were then removed and the contents were emptied. The segments were then filled with ice cold citrate buffer and were clamped and palpated for $5 \mathrm{~min}$ on ice-cold plate to release epithelial cells. The clamps were then removed and epithelial cells emptied. The enterocytes were collected at $500 \times g$ for $10 \mathrm{~min}$. The enterocytes were then homogenized in $0.0425 \mathrm{M} \mathrm{Na}_{2} \mathrm{HPO}_{4}, 0.02 \mathrm{M} \mathrm{KH}_{2} \mathrm{PO}_{4}$, $0.25 \mathrm{M}$ sucrose, $1 \%$ dextran, $10 \mathrm{mM} \mathrm{MgCl}_{2}$, pH 7.2, with three strokes in glass-Teflon homogenizer. The cells were then further fractionated in a Parr Bomb (Parr Instrument Co., Moline, IL) at 1000 PSI for $60 \mathrm{~min}$. The slowly discharged cell fractions were then layered on an unbuffered aqueous 1.25 M sucrose pad (13) and were centrifuged in SW28 rotor non-stop in the following manner: at $3300 \times g$ for $10 \mathrm{~min}, 13,200 \times g$ for $10 \mathrm{~min}$, and $82,600 \times g$ for $45 \mathrm{~min}$.

The Golgi-rich fraction appears as a white band at the interface. This band is then diluted in $260 \mathrm{mM}$ sucrose and $5 \mathrm{mM}$ imidazole, $\mathrm{pH} 7.2$, and the Golgi is collected at $60,000 \times g$ for $30 \mathrm{~min}$.

Marker enzyme enrichment. Galactosyl transferase, a marker of Golgi, was measured as described by Moore et al. (14). Cytochrome-C-reductase and oxidase markers of endoplasmic reticulum and mitochondria, respectively, were measured as described by Beaufy et al. (15). $\mathrm{Na}^{+}-\mathrm{K}^{+}$ATPase, a marker for basolateral membrane was measured by method of Scharschmidt et al. (16). Protein was measured by method of Lowry et al. (17) using bovine serum albumin as the standard.

Transport measurement. Uptake of calcium was measured by a rapid filtration technique (18). Briefly Golgi vesicles were preincubated in a transport buffer $(260 \mathrm{mM}$ sucrose, $5 \mathrm{mM}$ imidazole, $\mathrm{pH}$ 7.2) and uptake was initiated by addition of $20 \mu 1$ of vesicle to $80 \mu \mathrm{l}$ of labeled incubation media. The final concentrations of constituents were: $130 \mathrm{mM} \mathrm{KCl}, 1.3 \mathrm{mM}$ EGTA, 1 $\mathrm{mM} \mathrm{MgCl}_{2}, 27.5 \mathrm{mM}$ imidazole, $0.11 \mathrm{mM}$ dinitrophenol, 1.1 $\mathrm{mM} \mathrm{NaN}_{3}, 1 \mu \mathrm{M}$ free calcium, and $3 \mathrm{mM} \mathrm{MgATP}$. Micromolar concentration of free calcium was obtained by Ca-EGTA buffering system as detailed by Pershadsingh and McDonald (19). All experiments were performed at $25^{\circ} \mathrm{C}$ unless indicated. The reaction was stopped by addition of $1 \mathrm{ml}$ of ice-cold stop solution containing $100 \mathrm{mM}$ Mannitol, $100 \mathrm{mM} \mathrm{MgCl}_{2}$ and $20 \mathrm{mM} \mathrm{4-}$ (2-hydroethyl-1-piperazinepropane-sulfonic acid/Tris, pH 7.2. The vesicles were filtered immediately over cellulose nitrate filter $(0.45-\mu \mathrm{m}$ pore size, Sartorius Filters, Inc., Hayward, CA) under suction and washed with $5 \mathrm{ml}$ of stop solution. The amount of radioactive substrate remaining on the filter was determined in a liquid scintillation counter (Beckman Instruments, Palo Alto, CA), using Scinti Verse II (Fisher Scientific, Norcross, GA) as a liquid scintillant.

Materials. ${ }^{45} \mathrm{Ca}(10-40 \mathrm{mCi} / \mathrm{mg})$ was obtained from $\mathrm{New}$ England Nuclear (Boston, MA). Chemicals were obtained from Sigma Chemical Corp. (St. Louis, MO). Cellulose nitrate filters were obtained from Sartorius Filters, Inc. (Hayward, CA). 1,25 Dihydroxyvitamin $\mathrm{D}_{3}$ was measured by radioreceptor assay (Immuno Nuclear Corp., Stillwater, MN). Calcijex $\left(1,25-(\mathrm{OH})_{2}\right.$ vitamin $\mathrm{D}_{3} 1 \mu \mathrm{g} / \mathrm{ml}$ ) was kindly provided by Abbott Laboratories (Abbott Park, IL).

\section{RESULTS}

Purity of Golgi vesicles. The specific activities of enzyme markers in Golgi vesicles and crude homogenate are shown in Table 1 . As seen the activities of $\mathrm{Na}^{+}-\mathrm{K}^{+}$-ATPase, cytochrome-
$\mathrm{C}$-oxidase, and reductase markers of basolateral membrane, mitochondria, and endoplasmic reticulum respectively were impoverished. The activity of galactosyl transferase a marker of Golgi was enriched 34 times. Similar enrichment was obtained for all age groups.

ATP-driven calcium uptake with time. Figure 1 shows ATPdriven calcium uptake. In the presence of ATP, $\mathrm{Ca}^{++}$uptake was stimulated several-fold compared to no ATP conditions in adolescent, weanling, and suckling rats. Maximal uptake occurred at $15 \mathrm{~min}$ and was significantly greater in adolescent rats compared to suckling and weanling rats $(p<0.01)$. To determine the requirement for the hydrolysis of the $\beta$ - $\gamma$-phosphodiester bond for the stimulatory effect of ATP, we investigated the effect of $5 \mathrm{mM}$ of a nonhydrolyzable ATP analogue AMP-PCP on calcium uptake. The specificity of the adenosine base was tested by the addition of $5 \mathrm{mM}$ CTP to the incubation media instead of ATP. Both AMP-PCP and CTP decreased calcium uptake by $70 \%$ compared to uptake values with ATP.

Calcium uptake versus binding. To determine whether calcium uptake by Golgi vesicles is by a carrier mediated transport process or mere binding, we studied the effect of temperature on calcium uptake. Calcium uptake by Golgi vesicles was minimal at $0^{\circ} \mathrm{C}$ compared to $25^{\circ} \mathrm{C}$ suggesting that calcium uptake is an energydependent process rather than binding (Fig. 2). Furthermore the effect of calcium ionophore A-23187 at $10 \mu \mathrm{g} / \mathrm{mg}$ protein on calcium efflux from calcium loaded Golgi vesicles was determined. As seen in Figure 3 calcium efflux occurred rapidly suggesting that calcium was present in the intravesicular space rather than bound to the external surface. Clearly some calcium

Table 1. Sp act of enzyme markers in intestinal Golgi vesicles and crude homogenate in adolescent rats*

\begin{tabular}{lccc}
\hline & $\begin{array}{c}\text { Crude } \\
\text { homogenate }\end{array}$ & $\begin{array}{c}\text { Golgi } \\
\text { vesicles }\end{array}$ & Enrichment \\
\hline $\mathrm{Na}^{+}-\mathrm{K}^{+}$ATPase & $0.835 \pm 0.01$ & $0.126 \pm 0.01$ & 0.15
\end{tabular}

$\mu \mathrm{mol}$ phosphate/mg pro-

tein/min

Cytochrome-C-oxidase

$\mu \mathrm{mol} / \mathrm{mg}$ protein $/ \mathrm{min}$

Cytochrome-C-reductase

$\mu \mathrm{mol} / \mathrm{mg}$ protein $/ \mathrm{min}$

Galactosyl transferase

$\mu \mathrm{mol} / \mathrm{mg} / \mathrm{protein} / \mathrm{h}$

$\begin{array}{ccc}9.7 \pm 2 & 0.82 \pm 0.2 & 0.08 \\ 20.5 \pm 2 & 1.42 \pm 0.2 & 0.07 \\ 0.29 \pm 0.2 & 9.9 \pm 2 & 34.0\end{array}$

* Values are mean \pm SEM of $(n=6)$. Similar enrichment factors were obtained in weanling and suckling rats.
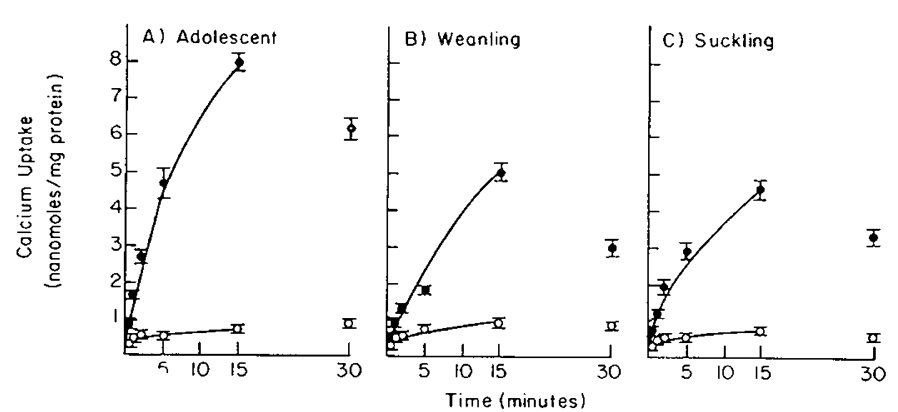

Fig. 1. Time course of calcium uptake in $2 \mathrm{wk}(A), 3 \mathrm{wk}(B)$, and 6 wk $(C)$ old rats in the presence and absence of ATP. Golgi vesicles were prepared in $260 \mathrm{mM}$ sucrose, $5 \mathrm{mM}$ imidazole, $\mathrm{pH}$ 7.2. Incubation was started by the addition of Golgi vesicles to a media containing in final concentration, either $130 \mathrm{mM} \mathrm{KCl}, 1.3 \mathrm{mM}$ EGTA, $1 \mathrm{mM} \mathrm{MgCl} 2,27.5$

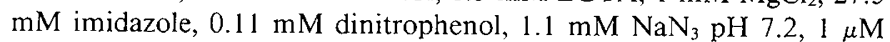
calcium, and tracer ${ }^{45} \mathrm{Ca}$ or similar solution except for the omission of ATP. Reaction was stopped at $15 \mathrm{~s}, 30 \mathrm{~s}$, and 1, 2, 5, 15, and $30 \mathrm{~min}$. Values are mean \pm SEM of three separate experiments on different membrane preparations $(n=9)$. 


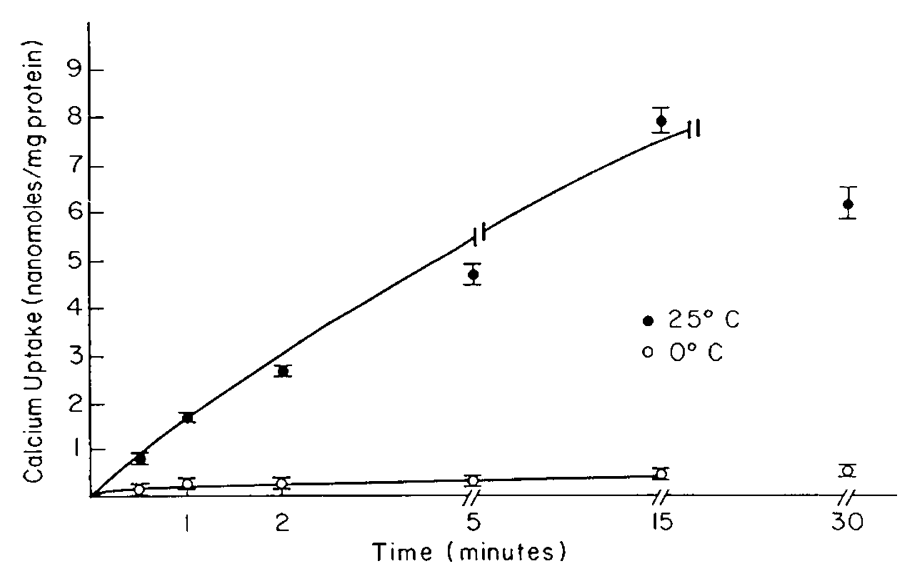

Fig. 2. Effect of temperature on calcium uptake by intestinal Golgi vesicles. Golgi vesicles were prepared in $260 \mathrm{mM}$ sucrose, $5 \mathrm{mM}$ imidazole $\mathrm{pH}$ 7.2. Incubation was started by the addition of Golgi vesicles to a media containing in final concentration $130 \mathrm{mM} \mathrm{KCl}, 1.3 \mathrm{mM}$ EGTA, $1 \mathrm{mM} \mathrm{MgCl} 2,27.5 \mathrm{mM}$ imidazole, $0.11 \mathrm{mM}$ dinitrophenol, $1.1 \mathrm{mM}$ $\mathrm{NaN}_{3} \mathrm{pH} 7.2,1 \mu \mathrm{M} \mathrm{CaCl}_{2}$, and tracer ${ }^{45} \mathrm{Ca}$. Calcium uptake was determined with time at 25 and $0^{\circ} \mathrm{C}$. Values are mean \pm SEM of three separate experiments on different membrane preparations $(n=9)$.

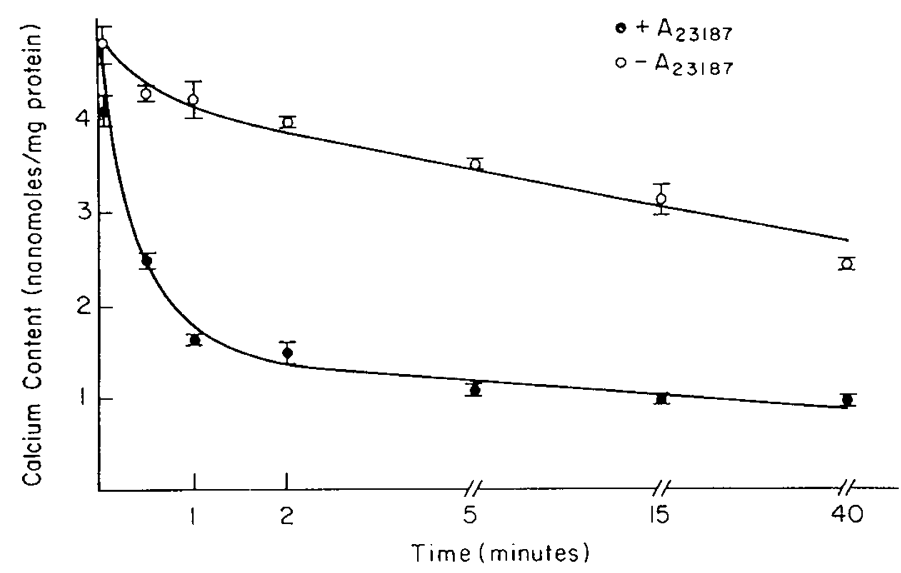

Fig. 3. Effect of calcium ionophore A23187 on calcium efflux from intestinal Golgi vesicles. Golgi vesicles were prepared in $260 \mathrm{mM}$ sucrose and $5 \mathrm{mM}$ imidazole $\mathrm{pH} 7.2$. Vesicles were loaded with $1 \mu \mathrm{M} \mathrm{CaCl}_{2}$ and ${ }^{45} \mathrm{Ca}$ in a similar incubation media to that described for calcium uptake studies with ATP. Calcium efflux was initiated by diluting loaded vesicles in a similar incubation with $10 \mu \mathrm{g} / \mathrm{mg}$ protein of A23187. Calcium efflux was determined with time. Values are expressed as percent of initial values at zero time points. Each point represents mean \pm SEM of $(n=$ 6).

remains in the intravesicular compartment bound to the negatively charged membranes.

Initial rate uptake. To investigate the linearity of ATP-dependent calcium uptake for determination of kinetic parameters we performed the initial rate uptake. Calcium uptake was linear up to $40 \mathrm{~s}$ (Fig. 4). Therefore kinetic studies were done at $15 \mathrm{~s}$ well within the linear phase of transport.

Kinetics of calcium uptake. Figure 5 shows the kinetics of calcium uptake in adult, weanling, and suckling rats. Calcium uptake was determined at free calcium concentrations of $0.04-$ $1.0 \mu \mathrm{M}$ in the presence and absence of ATP. $\mathrm{Km}$ and $\mathrm{V}_{\max }$ were calculated using a computerized model of Michaelis-Menten kinetics (20). $\mathrm{V}_{\max }$ values were $0.99 \pm 0.05,0.55 \pm 0.04$, and $0.29 \pm 0.03 \mathrm{nmol} / \mathrm{mg}$ protein $/ 15 \mathrm{~s}$ for adolescent, weanling and suckling rats, respectively. $\mathrm{Km}$ values were $0.16 \pm 0.02,0.12 \pm$ 0.03 , and $0.07 \pm 0.02 \mu \mathrm{M}$ for adolescent, weanling, and suckling rats, respectively. The $\mathrm{Km}$ and $\mathrm{V}_{\max }$ were significantly different

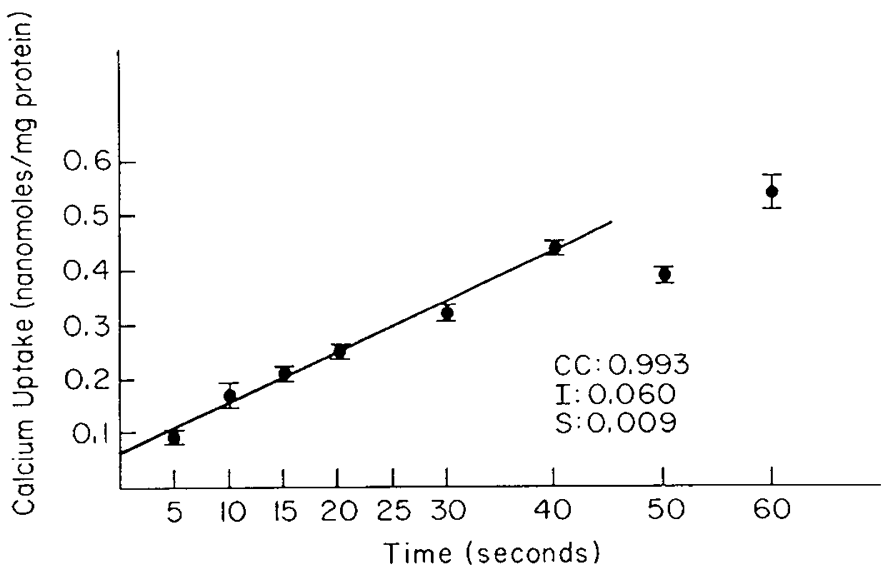

Fig. 4. Initial rate uptake of calcium. Intestinal Golgi vesicles were prepared in $260 \mathrm{mM}$ sucrose and $5 \mathrm{mM}$ imidazole $\mathrm{pH}$ 7.2. Incubation was started by the addition of Golgi vesicles to a media containing in final concentration, $130 \mathrm{mM} \mathrm{KCl}, 1.3 \mathrm{mM}$ EGTA, $1 \mathrm{mM} \mathrm{MgCl} 2,27.5$ $\mathrm{mM}$ imidazole, $0.11 \mathrm{mM}$ dinitrophenol, $1.1 \mathrm{mM} \mathrm{NaN}_{3} \mathrm{pH} 7.2,2 \mathrm{mM}$ ATP, $1 \mu \mathrm{M} \mathrm{CaCl}_{2}$, and tracer ${ }^{45} \mathrm{Ca}$. Calcium uptake was determined with $\mathrm{Km}$ and $\mathrm{V}_{\max }$ values were significantly greater in adolescent rat vesicles compared to suckling rat vesicles $(p<0.5-0.01)$.

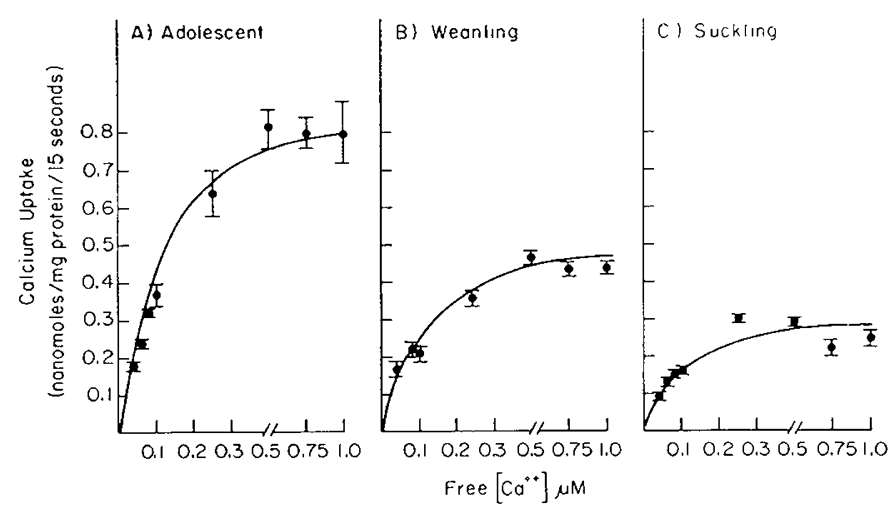

Fig. 5. Kinetics of calcium uptake. Intestinal Golgi vesicles were prepared in $260 \mathrm{mM}$ sucrose and $5 \mathrm{mM}$ imidazole buffer $\mathrm{pH}$ 7.2. ATPdependent calcium uptake was determined at $15 \mathrm{~s}$ with a range of calcium concentrations in the media from $0.05-1.0 \mu \mathrm{M}$. Kinetic parameters were obtained using a computerized model of the Michaelis-Menten kinetics. $\mathrm{Km}$ and $\mathrm{V}_{\max }$ values were significantly greater in adolescent rat vesicles compared to suckling rat vesicles $(p<0.5-0.01)$.

for adolescent and suckling rats $(p<0.001)$. The weanling rats values were intermediate. The calcium-dependent regulatory protein calmodulin has been shown to modulate calcium transport in small intestinal basolateral membrane vesicles $(21,22)$. We therefore examined the role of calmodulin on calcium uptake by Golgi vesicles. There was no effect on ATP-dependent calcium uptake when Golgi vesicles were preincubated in $10 \mu \mathrm{g} / \mathrm{ml}$ of calmodulin for $30 \mathrm{~min}$ and added to the incubation media containing $10 \mu \mathrm{g} / \mathrm{ml}$ of calmodulin.

Effect of vitamin D on calcium uptake. Vitamin D deficiency in adolescent rats was induced by feeding weanling rats vitamin D-deficient diet for $4 \mathrm{wk}$ while being kept in the dark. Vitamin $\mathrm{D}$ deficiency in suckling rats was induced by feeding time pregnant dams (day 2 of pregnancy) vitamin D-deficient diet and upon delivery the pups suckled from mothers milk while kept on the same diet and in the dark. Serum levels of $1,25-(\mathrm{OH})_{2}$ vitamin $\mathrm{D}_{3}$ was significantly decreased in suckling and adolescent rats compared to controls (Table 2). 1,25-(OH) 1 vitamin $\mathrm{D}_{3}$ levels were increased after intraperitoneal administration of the vitamin.

As seen in Figure 6, calcium uptake by Golgi vesicles of 
suckling rats was stimulated by intraperitoneal injection of 25 pmol of $1,25(\mathrm{OH})_{2}$ vitamin $\mathrm{D}_{3} 8 \mathrm{~h}$ before study as compared to control-deficient rats. To determine the nature of this stimulation, kinetic studies were conducted. As seen in Figure 7, a $\mathrm{V}_{\max }$ of $0.58 \pm 0.03$ in the injected rats, was seen as compared to 0.17 $\pm 0.03 \mathrm{nmol} / \mathrm{mg}$ protein $/ 15 \mathrm{~s}$ in the vitamin D-deficient rats $(p$ $<0.01)$. However the $\mathrm{Km}$ values were similar $0.11 \pm 0.02$ and $0.13 \pm 0.06 \mu \mathrm{M}$ for injected and deficient rats, respectively, indicating that vitamin $D$ increased the number and/or the activity of the carrier without an effect on the affinity of carrier. Similarly, vitamin $\mathrm{D}$ increased the $\mathrm{V}_{\max }$ in weanling and adolescent rats (data not shown).

\section{DISCUSSION}

The present studies characterize for the first time the role of the Golgi apparatus in calcium uptake during maturation. We used a technique in which Golgi vesicles were prepared from fresh enterocytes. Using this technique, we have validated the purity of Golgi vesicles by marker enzyme studies in all age groups studied. The impoverishment of basolateral, brush border, mitochondrial and microsomal markers coupled with marked enrichment of galactosyl transferase suggests that we are dealing with highly purified Golgi preparation. Moreover, we used sodium azide and dinitrophenol in our preparation to inhibit any contaminating mitochondrial preparation. An ATPdependent calcium transport system is evident at all age groups studied, as determined by stimulation of calcium uptake in the presence of hydrolyzable ATP, whereas in the presence of AMPPCP, a nonhydrozable ATP analogue, no stimulation was seen. Moreover, the specificity of the adenosine base was shown by the lack of stimulation of calcium uptake by CTP. We have

Table 2. Serum concentration of 1,25-(OH $)_{2} \mathrm{D}_{3}$ in control rats, vitamin $D$-deficient rats and in vitamin $D$-deficient rats injected with $1,25-(\mathrm{OH})_{2} \mathrm{D}_{3} *$

\begin{tabular}{lrlc}
\hline & Control & $\begin{array}{c}\text { Vitamin D } \\
\text { deficient }\end{array}$ & $\begin{array}{c}\text { Vitamin D deficient } \\
\text { injected with } \\
1,25(\mathrm{OH})_{2} \mathrm{D}_{3}\end{array}$ \\
\hline Suckling rats & $80 \pm 6$ & $12 \pm 5$ & $93 \pm 10$ \\
Adolescent rats & $157 \pm 2$ & $41 \pm 10$ & $192 \pm 12$ \\
\hline
\end{tabular}

$*$ Values are $\mathrm{pg} / \mathrm{ml}$ and represent mean $\pm \operatorname{SEM}(n=6)$ samples from suckling rats were pooled (each pooled samples represents one litter).

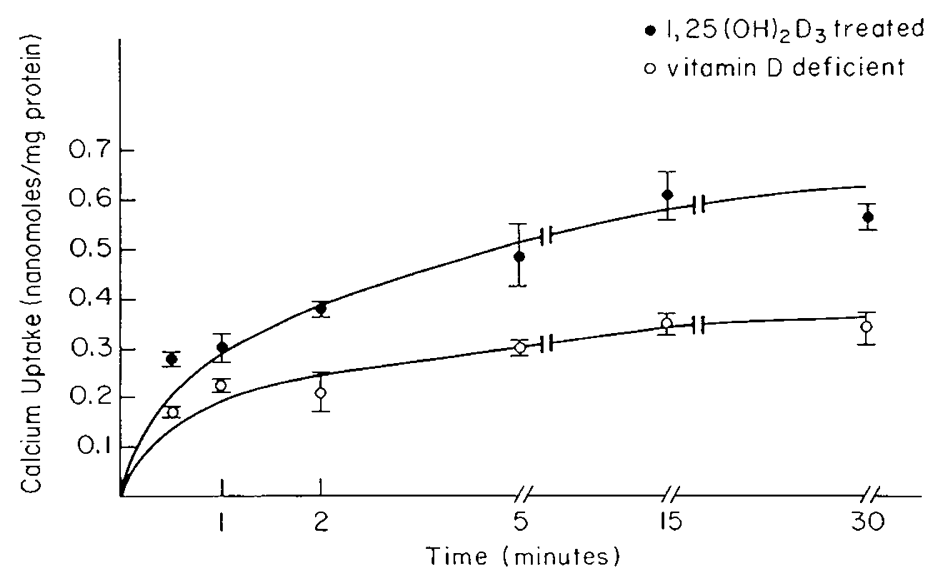

Fig. 6. Calcium uptake in Golgi vesicles from vitamin D-deficient and $1,25-(\mathrm{OH})_{2} \mathrm{D}_{3}$-treated rats. Intestinal Golgi vesicles from vitamin $\mathrm{D}$ deficient and $1,25-(\mathrm{OH})_{2}$ vitamin $\mathrm{D}_{3}$-treated $(25 \mathrm{pmol} / \mathrm{rats}$ intraperitoneally) suckling rats were prepared in sucrose buffer $\mathrm{pH}$ 7.2. Golgi vesicles were prepared $8 \mathrm{~h}$ after vitamin $\mathrm{D}$ treatment. Calcium uptake was determined with time in a similar media to that described for Figure 1. Values represent mean $\pm \operatorname{SEM}$ of $(n=6)$.

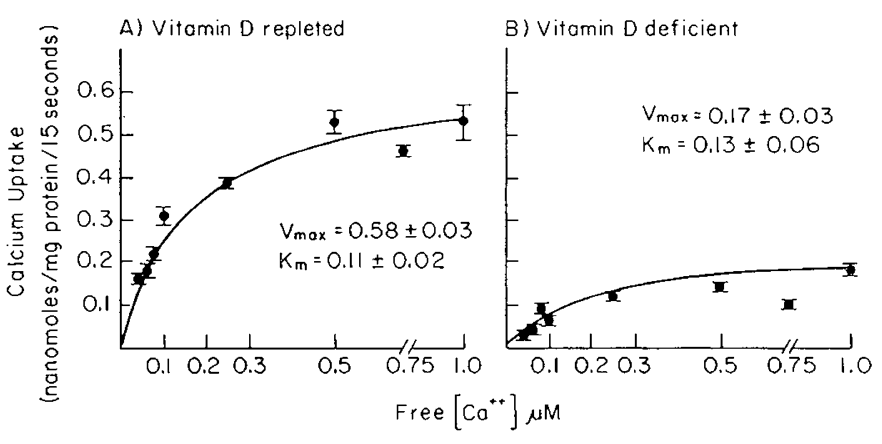

Fig. 7. Kinetics of calcium uptake in Golgi vesicles from vitamin $D$ deficient- and $1,25-(\mathrm{OH})_{2} \mathrm{D}_{3}$-treated suckling rats. Intestinal Golgi vesicles from vitamin $\mathrm{D}$-deficient and $1,25-(\mathrm{OH})_{2} \mathrm{D}_{3}$-treated $(25 \mathrm{pmol} / \mathrm{rat}$ intraperitoneally) suckling rats were prepared in sucrose buffer, $\mathrm{pH}$ 7.2. Golgi vesicles were prepared $8 \mathrm{~h}$ after vitamin D treatment. ATPdependent calcium uptake was determined at $15 \mathrm{~s}$ in a media containing different calcium concentrations $0.05-1 \mu \mathrm{M}$. Kinetic parameters were obtained using a computerized model of the Michaelis-Menten kinetics. $\mathrm{Km}$ values in both groups were similar, however $\mathrm{V}_{\max }$ in treated group was significantly greater compared to vitamin D-deficient group $(p<$ 0.01 ).

performed two studies to determine that we are dealing with intravesicular transport rather than binding. First, a temperature dependency study was conducted in which calcium transport was determined with time at 25 and $0^{\circ} \mathrm{C}$. As can be seen in Figure 2, calcium uptake was markedly decreased at $0^{\circ} \mathrm{C}$ suggesting that calcium uptake represents a carrier-mediated energydependent process. Carrier-mediated phenomena in general are temperature dependent (23) and binding is more apparent with lower temperatures (24) when carrier-mediated processes are suppressed. Second, calcium efflux studies using calcium ionophore A23187 were used. As seen in Figure 3, calcium release occurred rapidly in the presence of the ionophore suggesting that calcium was present in the intravesicular space rather than bound. We have used similar experiments for brush border (25) and basolateral membrane vesicles (26) to show that calcium was present in the intravesicular space. Therefore, our studies clearly demonstrate that calcium was transported into the intravesicular space rather than bound to the external surface of the vesicles. The characteristics and ontogeny of the transport systems for intestinal basolateral and microsomal uptake is quite different from that of Golgi uptake $(26,27)$, whereas calcium uptake in basolateral and microsomal membrane vesicles decreased with advancing age, the opposite is characteristic of uptake by Golgi vesicles. The ATP-dependent mechanism of calcium transport by intestinal Golgi vesicles in adult rats has been described recently (28). However, the kinetics of this system has not been determined. An ATP-dependent calcium transport system has been characterized in the lactating mammary gland of the rat. ATP-dependent calcium uptake exhibited a $\mathrm{Km}$ of $0.14 \mu \mathrm{M}$ and $\mathrm{a} \mathrm{V}_{\max }$ of $3.1 \mathrm{nmol} / \mathrm{min} / \mathrm{mg}$ protein (29). These kinetic properties show a close resemblance to our data with $\mathrm{Km}$ value of $0.16,0.12$, and $0.07 \mu \mathrm{M}$ for adolescent, weanling, and suckling rat intestinal Golgi vesicles, respectively. The $V_{\max }$ is also similar in both systems. Calmodulin, a calcium regulatory protein has been shown to modulate calcium transport in a variety of tissues including basolateral membranes (22). Red blood cells (30) and sarcoplasmic reticulum (31) have no effect on our kinetic parameters. Similar findings in regard to the effect of calmodulin were reported for ATP-dependent calcium transport by Golgi vesicles of the mammary gland of the rat (29) and the mouse (32). To determine the role of vitamin $D$ in the process of calcium uptake by Golgi vesicles, we used a vitamin D-deficient diet model in which pregnant rats were fed a vitamin D-deficient diet from the second day of pregnancy and kept in the dark. At 2 wk postpartum, the suckling rats had low levels of $1,25-(\mathrm{OH})_{2}$ vitamin $\mathrm{D}_{3}$. This model was developed after Hal- 
loran and Deluca (33), who showed that vitamin D deficiency does not interfere with pregnancy in the rat. $1,25-(\mathrm{OH})_{2}$ vitamin $\mathrm{D}_{3}$ levels were significantly decreased compared to controls and increased markedly $8 \mathrm{~h}$ after $1,25-(\mathrm{OH})_{2}$ vitamin $\mathrm{D}_{3}$ administration. 1,25-(OH $)_{2}$ vitamin $\mathrm{D}_{3}$ administration significantly enhanced calcium uptake by Golgi vesicles at all age groups studied. This effect occurs through an increase in $V_{\max }$ of the transport system suggesting that vitamin $D$ increases the number of the transport system carriers. Of significance is the finding of the stimulatory effect in suckling rat Golgi vesicles because previous animal studies using in vivo perfusion technique failed to show an effect of vitamin D on the overall transport system of calcium (34). We believe that the reason for failure to show an effect of vitamin $\mathrm{D}$ in vivo in the suckling rat relates to the fact that the majority of calcium is transported by a passive process during this period which may mask any effect on the active process. The large component of passive (nonsaturable) transport has been shown by our laboratory using in vivo (35) and everted gut sacs (36). Therefore, our studies demonstrate for the first time a vitamin D-dependent calcium transport in the Golgi membranes during maturation in the rat. Such mechanism may have a role in the regulation of cytosolic calcium movement. More recently, Van Corven et al. (37) have shown that the activity of the basolateral Ca-ATPase pump activated by proteases when basolateral membranes were prepared from enterocytes of vitamin D-deficient rats isolated by citrate buffer. Whether similar inactivation occurs with the ATP dependent calcium pump at Golgi vesicles remains to be determined.

\section{REFERENCES}

1. Feher JJ, Wassermann RH 1979 Evidence for a membrane-bound form of chick intestinal calcium binding protein. Biochem Biophys Acta 585:599610

2. Shimura F, Wassermann KH 1984 Membrane associated vitamin D induced calcium binding protein. Endocrinology 115:1964-1972

3. Thorens B, Roth J, Norman AW, Perrelet A, Orci L 1982 Immunocytochemical localization of the vitamin D-dependent calcium binding protein in chick duodenum. J Cell Biol 94:115-122

4. Davis WL, Jones RG, Hagler HK 1979 Calcium containing lysosomes in the normal chick duodenum: a histochemical and analytical electron microscopic study. Tissue Cell 11:127-138

5. Kikuchi T, Kikuchi K, Arab N, Ghishan FK 1987 Intestinal maturation: Characterization of the mitochondrial calcium $\left(\mathrm{Ca}^{++}\right)$transport system in jejunal enterocytes of rats. Gastroenterology 92:1464

6. Rubinoff $M$, Nellans $H N 1985$ Active calcium sequestration by intestinal microsomes. J Biol Chem 260:7824-7828

7. Walters JRF, Weiser MM 1984 Characterization of the vitamin D-dependent $\mathrm{Ca}^{++}$binding sites in rat intestinal Golgi-enriched membrane fraction. Biochem J 218:347-354

8. Walters JRF, Horvath PJ, Weiser MM 1986 Preparation of subcellular membranes from rat intestinal scraping or isolated cells: different $\mathrm{Ca}^{++}$binding, non-esterified fatty acid levels and lipolytic activity. Gastroenterology 91:3440

9. Warner RR, Coleman JR 1975 Electron probe analysis of calcium transport by small intestine. J Cell Biol 64:547

10. Mclaughlin J, Weiser MM, Freedman RA 1980 Biphasic recovery of vitamin D-dependent $\mathrm{Ca}^{++}$uptake by rat intestinal Golgi membranes. Gastroenterology 78:325-332

11. Gleason W, Landford G 1982 Intestinal calcium binding protein in the developing rat duodenum. Pediatr Res 16:403-407

12. Weiser MM 1973 Intestinal epithelial cell surface membrane glycoprotein synthesis. J Biol Chem 248:2536-2541

13. Swift LL, Soulé PD, Gray ME, LeQuire VS 1984 Intestinal lipoprotein synthesis: Comparison of nascent Golgi lipoproteins from Chow-fed and hypercholesterolemic rats. J Lipid Res 25:1-13

14. Moore DJ, Merlin LM, Keenan TW 1979 Localization of glycosyl transferase activities in a Golgi apparatus-rich fraction isolated from rat liver. Biochem Biophys Res Commun 37:813-819

15. Beaufy H, Costesec AA, Feytmans F, Wibo M, Robbi M, Berthet J 1974 Analytical study of microsomes and isolated subcellular membranes from rat liver. J Cell Biol 6:188-200

16. Scharschmidt BF, Keefe EB, Blankenship NM, Ockner RK 1979 Validation of a recording spectrophotometric method for measurement of membrane associated $\mathrm{Mg}^{++}$and $\mathrm{Na}^{+}-\mathrm{K}^{+}$-ATPase activity. J Lab Clin Med 93:790-799

17. Lowry OH, Rosebrough NJ, Lewisfarr A, Randall RJ 1951 Protein measurement with the folin phenol reagent. J Biol Chem 193:265-275

18. Ghishan FK, Wilson FA 1985 Developmental maturation of D-glucose transport by rat jejunal brush border membrane vesicles. Am J Physiol 248:G87-

19. Pershadsingh HA, McDonald TM 1980 A high affinity calcium-stimulated magnesium dependent adenosine triphosphatase in rat adipocyte plasma membranes. J Biol Chem 255:4048-4093

20. Vaughan WK, Neal RA, Anderson AJ 1976 Computer estimation of the parameters of the sigmoid kinetic model. Comput Biol Med G:1-5

21. Ghijsen W, Van Os CH, Heizman CW, Murer H 1986 Regulation of duodenal $\mathrm{Ca}^{++}$pump by calmodulin and vitamin $\mathrm{D}$-dependent $\mathrm{Ca}^{++}$binding protein. Am J Physiol 251:G223-229

22. Nellans HN, Popovitch JE 1981 Calmodulin regulated, ATP driven calcium transport by basolateral membranes of rat in small intestine. $J$ Biol Chem 256:9932-9936

23. Desmedt H, Kinner R 1981 Temperature dependence of solute transport and enzyme activities in hog renal brush border membrane vesicles. BBA 648:247-253

24. Schedl HP, Wilson H 1985 Calcium uptake by isolated brush border membranes vesicles. J Clin Invest 76:1871-1878

25. Ghishan FK, Arab N 1987 Developmental maturation of calcium transport by rat brush border membrane vesicles. Pediatr Res 22:173-176

26. Ghishan FK, Dannan G, Arab N, Kikuchi K 1987 Intestinal maturation: Calcium transport by basolateral membranes. Pediatr Res 21:257-260

27. Ghishan FK, Arab N 1988 Active calcium transport by intestinal endoplasmic reticulum during maturation. Am J Physiol 254:G74-80

28. Walters JRF, Weiser MM 1984 Relationship of non-esterified fatty acids to vitamin $\mathrm{D}$-dependent $\mathrm{Ca}^{++}$binding by rat intestinal Golgi vesicles enriched membrane fractions. Biochem J 218:355-360

29. Virk S, Kirk C, Shears S $1985 \mathrm{Ca}^{++}$transport and calcium dependent ATP hydrolysis by Golgi vesicles from lactating rat mammary gland. Biochem $\mathbf{J}$ 226:741-748

30. Niggli V, Adunyah ES, Penniston JT, Carafoli E 1981 Purified $\mathrm{Ca}^{++}-\mathrm{Mg}^{++}$ ATPase of the erythrocyte membranes. J Biol Chem 256:395-401

31. Lopaschuk G, Richter B, Katz S 1980 Characterization of calmodulin effects on calcium transport in cardiac microsomes enriched in sarcoplasmic reticulum. Biochemistry 19:5603-5607

32. Watters CD 1984 A calcium stimulated adenosine triphosphate in Golgi
alum. Bochemistry 19:5603-5607 enriched membranes of lactating murine mammary tissue. Biochem J 224:39-45 33. Halloran BP, Deluca HF 1979 Vitamin D deficiency and reproduction in rats.
Science 204:74-76

34. Toverud SU, Dostal L 1986 Calcium absorption during development: experimental studies of the gut small intestine. J Pediatr Gastroenterol Nutr 5:688695

35. Ghishan FK, Jenkins JT, Younoszai MK 1980 Maturation of calcium transport in the rat small and large intestine. J Nutr 110:1622-1628

36. Ghishan FK, Parker PH, Nichols S, Hoyumpa A 1984 Kinetics of intestinal calcium transport during maturation in the rat. Pediatr Res 18:235-239

37. Van Corvin EJJM, de Jong MD, Van Os CH 1987 The adenosine triphosphatedependent calcium pump in rat small intestine: Effects of vitamin D deficiency and cell isolation method. Endocrinology 120:868-873 